Illinois State University

ISU ReD: Research and eData

Theses and Dissertations

$5-22-2019$

\title{
Conceiving a "Veneration for Clowns": Popular Amusement and Social Subversion in the novels of Charles Dickens
}

Abigail Palmisano

Illinois State University, abigail.palmisano@gmail.com

Follow this and additional works at: https://ir.library.illinoisstate.edu/etd

Part of the English Language and Literature Commons

\section{Recommended Citation}

Palmisano, Abigail, "Conceiving a "Veneration for Clowns": Popular Amusement and Social Subversion in the novels of Charles Dickens" (2019). Theses and Dissertations. 1133.

https://ir.library.illinoisstate.edu/etd/1133

This Thesis is brought to you for free and open access by ISU ReD: Research and eData. It has been accepted for inclusion in Theses and Dissertations by an authorized administrator of ISU ReD: Research and eData. For more information, please contact ISUReD@ilstu.edu. 


\title{
CONCEIVING A “VENERATION FOR CLOWNS”: POPULAR AMUSEMENT AND SOCIAL SUBVERSION IN THE NOVELS OF CHARLES DICKENS
}

\begin{abstract}
ABIGAIL PALMISANO
58 Pages

Despite the immense popularity of common street amusements in the Victorian era, the allocation of leisure time to the venue of ribald diversions was often deprecated by moralists. In argument that theatrics depicting bawdy and often violent scenes would invite undesirable behavior into the habits of their audience, moralists decried the participation in such amusements amongst the common people. It was an assumed that those who frequented popular amusements were permissive of the licentious; to be an actor or creator of such theatrics was to be licentious in character. Curiously, this sentiment was not shared by well-known novelist and moralist, Charles Dickens, who believed characters met in amusement could be found in common life. In utilizing the structural frame of popular entertainment in his characters and plotlines, Dickens's novels offer a variant perception of the world to his reader, a perception that acknowledges the exaggerated and chaotic nature of social circumstances of Victorian society. This new perception, gained by Nicholas through his interaction with Crummles's troupe of thespians, allows him to function subversively within Victorian society, thus rectifying the wrongs done to his loved ones and himself.
\end{abstract}

KEYWORDS: Dickens, Circus, Pantomime, Melodrama, Punch and Judy, Theatre 


\section{CONCEIVING A "VENERATION FOR CLOWNS": POPULAR AMUSEMENT AND SOCIAL SUBVERSION IN THE NOVELS OF CHARLES DICKENS}

ABIGAIL PALMISANO

A Thesis Submitted in Partial Fulfillment of the Requirements For the Degree of

\section{MASTER OF SCIENCE}

Department of English

\section{ILLINOIS STATE UNIVERSITY}


Copyright 2019 Abigail Palmisano 
CONCEIVING A "VENERATION FOR CLOWNS": POPULAR AMUSEMENT AND

SOCIAL SUBVERSION IN THE NOVELS OF CHARLES DICKENS

ABIGAIL PALMISANO

Committee Members:

Jan Susina, Chair

Tara Lyons 


\section{CONTENTS}

Page

$\begin{array}{ll}\text { INTRODUCTION } & 1\end{array}$

CHAPTER I: THE PANTOMIME OF LIFE

$\begin{array}{ll}\text { CHAPTER II: TRAGICAL COMEDY } & 18\end{array}$

CHAPTER III: CARNIVAL LAUGHTER 31

$\begin{array}{ll}\text { CONCLUSION } & 55\end{array}$

BIBLIOGRAPHY 


\section{INTRODUCTION}

In 1936, Charles Dickens took to the stage and authored two plays, "The Village Coquette" and the "The Strange Gentleman." Both shows were a success, and Dickens went on to compose four more plays (Axton 278). Dickens, however, never gained fame from his work as a playwright. Naturally, he was known as a prolific novelist, authoring dozens of books within his lifetime. Despite the apparent difference in genre between novel and drama, Dickens insisted that "every writer of fiction... writes, in effect, for the stage" (Axton 6). Dickens saw the novel as theatre presented in a different medium. Although not the visual and auditory medium of drama, the narrator deftly bridges play drama from the stage to the page through in-depth description of scenery, facial expression, voice, and mannerisms, essentially providing for the written tale a sense of scenery props, and live actors.

The theatricality of Dickens's novels moves far beyond scenery and facial expression. In fact, Dickens frequently borrows characters from the popular theatrical amusements such as the pantomime, melodrama, "The Punch and Judy Show," and the circus. This act of character borrowing has long been acknowledged by Dickens scholars, perhaps most notably by Edwin Eigner and William Axton. However, criticism has yet to consider the how these various artforms may be concurrently used by Dickens in his writing, and furthermore how characters of

these individual theatrical forms interact within his novels. Schlicke posits that "the main plot is a melodrama of heroes and villains, in which innocence is threatened, wickedness defeated and virtue rewarded. The action includes such stock player situations” (49). Dickens's Victorian contemporaries would have easily been able to recognize the figures of popular theatre within the 
characters and situations of Dickens's novels, given the immense popularity of these amusements.

Despite the wide popularity of common street amusements in the Victorian era, the allocation of leisure time to the venue of ribald diversions was often deprecated by moralists. In argument that theatrics depicting bawdy and often violent scenes would invite undesirable behavior into the habits of their audience, moralists decried the participation of such amusements amongst the common people. In the Oxford Reader's Companion to Dickens, Peter Schlicke states that "in the anxious debates in much of Victorian middle-class and religious world about the moral legitimacy of this or that form of leisure the underlying assumption was that leisure should invigorate you for work and be morally uplifting" (20). It was an assumed that those who frequented popular amusements were permissive of the licentious; to be an actor or creator of such theatrics was to be licentious in character. Curiously, this sentiment was not shared by wellknown novelist and moralist, Charles Dickens. Dickens applauded and harbored a deep love for illegitimate ${ }^{1}$ theater and street amusement of any kind. An amateur actor himself, and noted stage performer of his novels, Dickens encouraged the traditional forms of amusements that he had watched since childhood and consistently worked them into the narrative frame of his novels.

Rather than placing such a high value on illegitimate theatre, or popular amusement as it will henceforth be called, despite its socially subversive nature, Dickens valued it precisely for that quality. The specific ways in which popular amusement is depicted and used within Dickens's works reveals the utility of such subversion. The oppressed (socially, emotionally, or

\footnotetext{
1 "Legitimate theatre" was a term used by the Victorians to describe a select few theatres licensed to perform spoken drama. Any other theatre, then, was "illegitimate" and therefore wove song and dance into performance.
} 
otherwise), through viewing a staged subversion, become equipped with a comedic lens through which to view their lives. Acting within the framework of the comedic, as opposed to traditional social dictums, formerly oppressed characters gain a new sense of agency, allowing for healthy social upheaval and correction, both in the lives of the individual and others. The use of absurd and subversive theatrics to signify and encourage social subversion in the lives of Dickens's fictionalized characters are reflective of the novelist's belief that the characters portrayed in popular amusement were present in everyday life: "A Pantomime is to us a mirror of life; nay more, we maintain that it is so to audiences generally, although they are not aware of it, and that this very circumstance is the secret cause of their amusement and their delight" ("The Pantomime of Life" 501). In utilizing the structural frame of popular entertainment in his characters and plotlines, Dickens's novels offer a variant perception of the world to his reader, a perception that acknowledges the exaggerated and chaotic nature of social circumstances of Victorian society. This new perception, gained by Nicholas through his interaction with Crummles's troupe of thespians, the ever-amused John Brody, and the various stories to him allow Nicholas to function subversively within Victorian society, thus rectifying the wrongs done to his loved ones and himself. 


\section{CHAPTER I: THE PANTOMIME OF LIFE}

It is no secret that Dickens harbored a strong love for the theatre. From his early childhood, the theatre was a favorite source of entertainment for Dickens. So great was Dickens's love of the stage, that as a young man he seriously considered pursuing a career as a professional actor. However, after a brief illness that prevented a promising audition at Covent Garden, Dickens settled for making a hobby of amateur acting, and put on a number of shows with his family and close friends (Tomlin 48). Neither is Dickens's constant use of theatrical characters and tropes within his own works a new revelation. Various scholars have presented arguments that correlate Dickensian plots and characters to popular theatrical counterparts. Edwin Eigner connects the stock characters of the Christmas pantomime to various figures within Dickens's novels. In the case of Nicholas Nickleby, Eigner rightly poses Nicholas as Harlequin, Kate and Madeline as Columbine, and Ralph and Madeline's father as Pantaloon. Conversely, in his book Circle of Fire, William Axton suggests that Dickens derives his plots from Victorian melodrama. This also rings true; the basic plots of the pantomime and Melodrama are, in fact, nearly identical. Axton takes note of this, stating, "Whatever encouragement may have been given to its development by the tale of terror, the romantic novel, nautical song, and $18^{\text {th }}$ century sentimental comedy, Victorian melodrama had its most likely parent in pantomime" (24). The borders between the pantomime and the melodrama are notoriously thin.

This chapter will examine the correlations between the characters of popular amusement and the characters of Nicholas Nickleby, as well as the situations borrowed from the plots of pantomime, melodrama, "The Punch and Judy Show” and the circus. Although many critics have noted the numerous similarities between Dickens's novels and Victorian popular entertainment, most relegate Dickens's theatrical inspirations to a singular venue. A critic might suggest the 
influence of the pantomime, or the circus, or melodrama, but it is rare to find a suggestion of multiple theatrical sources, William Axton providing one of these rare examples. Dickens's novels, however, are fraught with characters and tropes from the Pantomime, Melodrama, Punch and Judy show and the circus. While this is far from surprising, especially given the fact that the characters of these art forms historically interacted with one another, it has yet to receive adequate critical attention. And yet, Victorian London was overflowing with theatrical sights and scenes. Some stages occurred spontaneously in common life, and Dickens delighted to witness the theatricality inveterate in the everyday behavior of the common Londoner. Such scenes fueled Dickens's colorful depictions of life featured in Sketches by Boz. Other theatrical practices were more official. From large theatres to itinerant puppet theatres, show business permeated every part of Victorian England.

The characters featured in these shows were the product of long and rich theatrical histories. In his forward to The Memoirs of Joseph Grimaldi, the Richard Findlater writes that the Pantomime was:

an entertainment derived from Parisian versions of the Italian comedy, or Commedia dell'Arte, and its gallery of characters, who had become international types by the end of the seventeenth century. They included a number of rascally servants such as Arlecchino, Pulcinello and Pedrolino, better known by their Franco-English avatars Harlequin, Punch and Pierrot; an amorous serving Colombina; and Pantalone, a miserly and amorous old merchant. (20)

While these characters eventually dispersed into the pantomime, melodrama, circus, and the "Punch and Judy Show," their historical interaction remains significant. Additionally, these various forms of entertainment and characters remained popular with the Victorians. It is only natural that they should interact on the stage of Dickens's novels. These characters appear in a 
number of Dickensian works but have an especially potent presence in Nicholas Nickleby. In this chapter, I will explore the correlation between five stock characters of Victorian popular entertainment and the leading players of Charles Dickens's novel Nicholas Nickleby.

The Pantomime, a popular Boxing Day amusement, began with a set of masked characters in a "fairyland" who become transformed by a magical agent into wild stock characters such as Pantaloon, Harlequin, Columbine, and Joey the Clown. Pantaloon the miserly father of Columbine, seeks to prevent the romance between his daughter and the trickster, Harlequin. This results in a long and elaborate chase that lasts for the majority of the show. The chase sequence often included various political and popular culture references. Harlequin quickly changes his location with the aid of a teleportative slapstick, which he receives from the magical agent.

Melodrama contains a similar plot: lovers are kept apart and must strive to preserve their relationship. However, unlike the death-defying escapades of the pantomime, melodrama often features rather dramatic death scenes. It deals out pathos rather than laughter. Victorian audiences relished the extreme pathos of the melodrama, and the overworked tragedy of this theatrical form made its way into the novel. The Old Curiosity Shop, for example, is famous for Little Nell's highly melodramatic death scene.

The "Punch and Judy Show" features a good deal of death and murder as well, but much like the Pantomime, it is performed with comedic flavor. As a puppet show performed by itinerant street artists, the plot takes its hero, Mr. Punch, from Pulcinello of the Commedia tradition. Mr. Punch is a violent hunchback who gains sadistic glee in the murder of his wife, child, local law enforcement, hangman, and on occasion, the devil. "The Punch and Judy Show" also plays a prominent role in The Old Curiosity Shop. For a time, Nell and her grandfather 
travel with a set of Punch performances, and the striking differences between each of the character's individual reactions to the famous puppet greatly feed into the drama of the novel. Finally, the Circus features many characters of the Commedia tradition, notably Pedrolino or Pierrot, the Sad Clown. Characters of the circus often perform pantomime routines on horseback — an act called "hippocommedia." Such an act is featured in the novel Hard Times. The circus also frequently featured popular characters from other forms of entertainment, such as the novel. In fact, a number of Dickens's characters appeared in the circus, including a number of the characters of Nicholas Nickleby, and the plot of the Pantomime provides the underlying structure for much of the novel.

Just as Hard Times and The Old Curiosity Shop contain characters from and performances of Victorian popular entertainment, Nicholas Nickleby utilizes theatrical characters on and off the stage. As Eigner suggests, the title character, Nicholas, fills the role of Harlequin within the novel's underlying Pantomimist structure. Axton notes that "a typical Christmas or Easter pantomime opened with a half-serious story of conflict between the lovers, and heavy father, an unwanted suitor, and a comic servant or old dame" (18). This plot structure appears twice within Nicholas Nickleby, first with Nicholas Ralph, and Kate (who, although not a love interest for Nicholas, is in a dislocated position from him while Ralph attempts to pawn her off to rich and unwanted suitors) and subsequently between Nicholas, Madeline Bray, and her father. Nicholas manages to save not one, but two damsels in distress from the grasp of greedy paternal control. All the while, Nicholas performs a comic and wild extended chase scene from Yorkshire to London.

However, Nicholas is not a born Harlequin, and at the beginning of the novel, Nicholas is overly trusting and naïve. The narrator insists that "It was very little that Nicholas knew of the world" (Nicholas Nickleby 45). In suit with his theatrical original, Nicholas must experience a 
dramatic moment of transformation. At the opening of the novel, Nicholas is rather innocent, and readily trusts his uncle's promises, including Ralph's claim that he will put Nicholas on the path of prosperity. As soon as Ralph confirms that Nicholas's "fortune will be made at once" through his employment to Wackford Squeers, Nicholas begins to conjure up a hopeful yet wildly unrealistic picture of the future:

"To be sure, I see it all," said poor Nicholas, delighted with a thousand visionary ideas that his good spirits and his inexperience were conjuring up before him. "Or suppose some young gentleman who is being educated at the Hall, were to take a fancy to me, and get his father to appoint me his when he left, and when we come back from the continent, procured me some handsome appointment." (28)

Unlike Harlequin, Nicholas has placed an undeserved trust in the rich. Nicholas is ready to act on the suggestion of a greedy old man, little suspecting that his uncle may be acting against his best interests. Harlequin cannot possess such naivety; in order for Harlequin to enact his trickery, he must first recognize the rich Pantaloon as his adversary, and furthermore acknowledge that society at large may not be concerned with his own happiness or welfare. Thus, Harlequin is necessarily critical of the world around him and takes action where necessary to establish the future that his society may not provide for him. This early Nicholas, on the other hand, has yet to gain enough experience to claim the agency to shape his own future.

Transformation is a key feature of the Victorian pantomime. Harlequin does not begin the play as Harlequin, but as the Boy. In this way, the early Nicholas does display a similarity to Harlequin; he must be transformed in order to gain a new active and effective identity. In the pantomime, it is a "magic agent" of some sort—perhaps a fairy or a devil— that initiates this scene of transformation. Axton notes that: 
When the struggle between the lovers and the father reached an impasse, a fairy interceded and with a magic wand instantly transformed the scene. The actors, who had previously underdressed (that is, had put on a second costume under their outer dress), meanwhile doffed their masks and street clothes stand revealed as the personages of the harlequinade. The two lovers became Harlequin and Columbine, the heavy father Pantaloon, and the rest clowns, mischievous followers of the lecherous, scheming, and gluttonous Pantaloon. (18)

Previous to the transformation, the male lover is typically played by a young woman dressed as a a stock character referred to as the Principal Boy. The Boy is transformed into the man Harlequin, and thereupon obtains his magic bat which provides him with the power of teleportation. Nicholas too must undergo a transformation from naïve teenager to a streetwise and bold young man who, while lacking supernatural teleportation, takes to gallivanting across the country in search of the future that he desires for his family and himself. What, then, is the agent that initiates such a transformation in Nicholas's life? Far, perhaps, from a benevolent fairy, Nicholas is transformed from the hell of Dotheboys Hall.

Wackford Squeers, the absurd and abusive headmaster of Dotheboys Hall is himself reminiscent of another figure from popular entertainment: the puppet, Mr. Punch, of the "Punch and Judy Show." A violent man with a marked deformity, who rather enjoys beating people with a stick, Squeers has a good deal in common with Mr. Punch. His uncontrollable rage and violence are unjudiciously aimed at anyone unfortunate enough to have made his acquaintance. Throughout Dickens's works, Punch figures are always antagonists. While the violence and trickery of Harlequin may gain the approbation of the moralist, the unbridled subversion enacted by Punch is consistently condemned. Daniel Quilp, the demonic dwarf of The Old Curiosity 
Shop is such a figure. Nicholas Nickleby even features secondary Punch characters: at the meeting of the United Metropolitan Improved Hot Muffin and Crumpet Baking and Punctual Delivery Company, a group of policemen attempting to control the crowd immediately began to drag forth, by coat tails and collars, all the quiet people near the door; at the same time dealing out various smart and tingling blows with their truncheons, after the manner of that ingenious actor, Mr. Punch: whose brilliant example, both in the fashion of his weapons and their use, this branch of the executive occasionally follows.

Like Punch, the policemen act on impulse (and laziness) directing their violence at those who are only guilty of standing in near proximity to them. It is an obstreperous violence that penalizes the innocent, often for crimes perpetrated by others who have the benefit of distance. The inner crowd of the meeting are those who cause the disturbance, but it is the bystanders who happen to be in arm's length of the policemen who feel the force of the law.

Similarly, the young boys of Dotheboys Hall are regularly penalized for the misdeeds of their guardians. When Squeers travels to London, advertising the school, he informs the stepfather of a potential pupil that most of his students are illegitimate children whose parents desire to be rid of them:

"What are these boys;--natural children?"

"No," rejoined Snawley, meeting the gaze of the schoolmaster's one eye.

"They ain't."

"I thought they might be," said Squeers, coolly. "We have a good many of them; that boy's one." (35)

Illegitimate children are sent away to Yorkshire to cover up the moral mishaps of their parents. Nor are the children safe from their parents' failure once they are school. When a parent cannot 
pay for their son's tuition, Squeers canes the child for it. The spatial dislocation of the parent prevents direct confrontation, and Squeers happily redirects his rage towards the children around him. He cares not for justice, but for the free expression of wrath. It is this characteristic that vitally differentiates Punch from Harlequin.

In contrast, Harlequin's rage is controlled and only seeks to target guilty parties. Nicholas experiences this more bridled and directed type of rage, which presents itself as a righteous anger. Physical violence comes as a last resort for Nicholas; it can only occur when peaceful methods of interference have been exhausted. Nicholas vocalizes these attempts to Squeers when he halts the schoolmaster's flogging of Smike:

You have disregarded my quiet interference in the miserable lad's behalf," said Nicholas; "you have returned no answer to the letter in which I begged forgiveness for him, and offered to be responsible that he would remain quietly here. Don't blame me for this public interference. You have brought it upon yourself; not I. (156)

Nicholas's action, furthermore, is the result of insults not just to himself, but to others-Smike and the other pupils of the school. Nicholas asserts that he has "a longs series of insults to avenge" and that his "indignation is aggravated by these dastardly cruelties practiced on helpless infancy in this foul den" (156). Citing one final warning, he states "Have a care; for if you do raise the devil within me, the consequences shall fall heavily upon your head!” (156). This last injunction is particularly interesting, seeing as it is one of several moments where Nicholas associates himself with the devil. Harlequin is an Anglicized version of the Italian "Arlecchino" a name believed to be taken from the devil Alichino from Dante's Inferno. The character archetype likewise has roots in the devils of Medieval morality plays. The devil holds a place of importance for Mr. Punch as well — the devil, being the last adversary that Punch meets on 
violent escapade, is the only figure to pose a legitimate threat to Punch (Leach 13). There is some disparity in the outcome of Punch's battle with the devil. At times, the devil finally kills

Punch, and at others, as demonstrated in the Cruikshank and Collier's illustrated Punch and Judy Show, Punch succeeds in overcoming the devil (34). In effect, Dickens transitions from the final scene of the Punch and Judy show to the opening of the Pantomime. Squeers must face the devil, that is, Nicholas, who ultimately prevails over him. Consecutively, Nicholas's boyish trust is transformed into active energy -transformed by Punch as a hellish agent. As Nicholas seizes Squeers's cane, or slapstick, he commences his own harlequinade.

There remains another pivotal figure within the transformation of Nicholas. Smike is representative of yet another type of popular entertainment: the circus. Smike is the Pierrot, the Sad Clown, the eternal miserable who wins the audience's laughter through his extreme pathos. The Sad Clown also plays an important role in the plot of the pantomime. Sad Clown is typically betrothed to Columbine, whose heart belongs to Harlequin. This aspect of the pantomime is mirrored within the plot of Nicholas Nickleby in Smike's undying love for Kate, who never feels any romantic interest for him.

Kate is the first Columbine featured in Nicholas Nickleby. Much like the Columbine of the pantomime, Kate finds herself trapped in the control of a greedy guardian, Ralph, who is far more interested in using his niece as a tool for financial gain than her physical and emotional wellbeing. Falling in line with damsel in distress paradigm, a woman who piously waits to be rescued by some masculine figure, Kate is often criticized by modern scholars as a character who lacks any legitimate agency. Michael Slater states that "Kate, Madeline, and Mary Graham are all the subject of their creator's strong moral approval but this is not enough for him to be able to breathe life into them; they remain one dimensional" (234). Slater attributes this lack of dimension to Dickens's tendency to typecast women into archetypes, in this case, the "Mary" 
archetype of the modest and moral woman who is subject to the perverted intentions of evil men, such as Mulberry Hawk or Arthur Gride. While this archetype does aptly describe both Kate and Madeline, but perhaps does not sufficiently account for the entirety of Kate's character.

The fact that Kate is drawn from the template of Columbine, however, raises the question of typecasting. Are Dickens's women, including Kate, dependent on the few theatrical types available? The question is legitimate but may find an answer in a comparison of the two Columbines of Nicholas Nickleby. While Madeline is rather helpless, accomplishing nothing except tears, Kate makes efforts to gain some level of agency. Eigner notes that Madeline encompasses the stereotypical self-sacrificing nature of Columbine and declares that she is "Dickens purest version of the character of the panto who gets transformed into Columbine and spends the erst of the evening in a long dress, skimming across the stage, alternately comforted by Harlequin and terrified by all others" (130). Eigner groups Kate into the same Columbine category as Madeline, but fails to address the differences in their attempts at personal agency. Kate is not nearly as helpless as Madeline. Therefore, while Dickens plays off of the classic Columbine figure, not every Columbine is drawn in the same way.

Kate, although ultimately saved by Nicholas, does attempt to forge her own future. Developing a disdain for her uncle's character early on, Kate confides in Miss La Creevy that "a dependence on him...should embitter my whole life. I should feel begging a far less degradation" (Dickens 118). Kate, in fact, makes efforts at independence, at far as independence is possible for a young Victorian woman. However, like Nicholas, Kate finds that working life only affords more trouble. Upon her first meeting at the milliner's shop, Kate is met with the uncomfortable gaze of Mr. Mantalini. While it is impossible for her to avoid the unwanted attention in itself, Kate does take pains to ensure that Mantalini's desire is never gratified. Kate determines not to look at Mantalini, "not daring to look up; for the she felt that the eyes of the odious man in the dressing 
gown were directed towards her" (127). Furthermore, when Mantalini is "anathematizing the stairs with great volubility as he followed them down, in the hope of inducing Kate to look round" it is "a hope, however which was destined to remain ungratified" (129). In the same scene, Kate strictly and intentionally controls the direction of her speech, addressing only Madame Matalini, even when spoken to by Mr. Mantalini (127). Although her available options for retaliation are small, Kate does in fact assert herself through her visual and verbal rhetoric regularly throughout the novel. Kate's attempt at independence indicates her departure from the pure Columbine type. Unlike Columbine and Madeline, she is not willing to sacrifice herself for her guardian. Kate wishes to be free of Ralph by any means necessary. It is not a matter of will but the width of socially acceptable forms of retaliation available that differentiate the efficacy of Nicholas from the ultimate dependence of Kate. Eigner suggests that Dickens's early female characters are figures of "thwarted potential" who "underscore a need for reformation of the basic assumptions about sexual identity and sexual roles" (131). If socially inscribed gender roles were different, it is likely that Kate would take on a greater level of independence and agency. This is demonstrated in the many similarities between Kate and

Nicholas, who is highly active. Both characters display strong emotional reactions, a desire for independence, and a disdain for the wrongdoing of those around them. Neither are passive characters, quite unlike Madeline. Nicholas, however, is able to physically retaliate and overcome Squeers and Hawk through his strength. Kate, in contrast, is left few means of protest, and must make do with censoring the recipients of her speech and visual attention. Nicholas, as a man, is also given the benefit of mobility. He is able act out with violence against those who have wronged his loved ones and himself precisely because he possesses the ability to escape afterwards. Nicholas can safely tramp about the country without fear of attack or harm. Not so with Kate. If, even in her small London community, supposedly under the protection of her 
mother and uncle, Kate experiences sexual harassment, she surely would be meet with worse if she took to the streets and made her escape. Given her lack of mobility, she must ameliorate her present circumstances through the small measures of speech.

Both Nicholas and Kate, as Harelquin and Columbine, are the enemies and character opposites of Ralph Nickleby, the Pantaloon of the novel. Ralph, in imitation of Pantaloon, is the old miserly guardian who gains control of others through his riches. Ralph provides a foil for both Nicholas and Kate on a number of fronts. Where his niece and nephew freely express their emotions, Ralph suppresses his own, chiding any expression of feeling, such as tears that he may see in those around him (123). His cupidity, too, distinguishes Ralph from his familial counterparts, and neatly aligns him with the character of Pantaloon. Kate and Nicholas state that they are content to beg if necessary, but Ralph values money above all.

The correlation between figures of popular amusement and the characters of Nicholas Nickleby isn't merely artistic in purpose. Dickens's stock characters possess a certain verisimilitude sourced from the reality of Victorian England. Early in his career, Dickens's under the pseudonym of Boz, wrote an essay called "The Pantomime of Life" in which he mused on the striking similarity between the exaggerated figures of the stage and the various characters met in everyday life: "A Pantomime is to us a mirror of life; nay more, we maintain that it is so to audiences generally, although they are not aware of it, and that this very circumstance is the secret cause of their amusement and delight" (501). We laugh because we see our reality on stage, a reality that we may not otherwise be able to confront.

Charles Dickens's fascination with the collapse of theatre into reality is far from a singular concern. In the Middle Ages, a number of urban legends circulated about actors who were actually crucified playing Jesus and who accidently hung themselves while playing Judas (Enders 63). This fear (and fascination) was apparently revived in the $19^{\text {th }}$ century by Ruggero 
Leoncavallo in his opera Pagliacci, in which a Commedia actor portraying the Sad Clown, Pagliacci, on stage finds himself in the cuckolded position of his character, and thus blends the lines between reality and show, actually stabbing Columbine (played by his wife) on stage. Dickens explores this confusion between reality and play in his book The Memoirs of Joseph Grimaldi, a biography of one the most famous pantomime actors. Dickens recounts an episode in which Grimaldi's father brutally beats him onstage. Since father and son were playing clowns, the audience believed this beating to be a part of the show and roared with laughter, completely unaware of the actual abuse experienced by the young Grimaldi (36).

The concern that stage may collapse into reality was shared by Victorian moralists, who theorized that the audiences who watched popular entertainment may begin to enact the violence and adultery that they witnessed onstage. Any form of "amusement" was highly suspect. Paul Schlicke states:

In the anxious debates of much of the Victorian middle-class and religious world about the moral legitimacy of this form of leisure the underlying assumption was that leisure should reinvigorate you for work and be morally uplifting; recreation should recreate you. 'Amusements' carried none of this moral baggage; their function was to amuse, to make people laugh, and to facilitate the indulgence of fantasy within an overarching and enabling sociability (20).

One journalist, as recorded by Robert Leach in The Punch and Judy Show, witnessed a young urchin push his fellows off pavement in 1854 and claimed the child "had learned his selfdetermination from Punch" (34). Some, however, took the opposite view; Louisa Jones notes that "Janin even claims that the working-class audience commits fewer crimes because of working out its aggressions at Funambules, where Pierrot does the kicking and gets kicked in return" (70). In either case, the possible relationship between life and stage is not lost upon $19^{\text {th }}$ 
century audiences, but continually negotiated and acted upon by them. Whether a person chooses to vent his or her aggression through viewership or to take the subversive action of the clown upon his or herself, the role of the audience member is not a passive one. Amusement both revealed the nature of the world that the audience lived in and served a social function in either mollifying the working-class or else girding them with new agency.

Dickens saw an opportunity in the seeming self-conscious approach of Victorian audiences to the amusements that they enjoyed. His reading audience, like the audience of the theater and street amusement, would recognize that novel's antagonists, such as Squeers, Ralph Nickleby, and Sir Mulberry Hawk, were more than mere characters; they were real people. In the "Pantomime of Life" Dickens declares, "of all the pantomime dramatis personal, we consider the pantaloons the most worthless and debauched...Is there any man who cannot count a dozen pantaloons in his own social circle?" (501-2). Heroes, too, are not left out of the schema of reality. Dickens further claims that "we see harlequins of so many kinds in the real living pantomime, that we hardly know which to select as the proper fellow of him of the theatre" (505). While the violence and trauma enacted by the villains of the stage are more than present in the Pantomime of life, the heroics of the common person are likewise apparent. It is through a faith in a self-conscious reader with the ability to recognize the reality in the fictional that Dickens is able to enact his social criticism. 


\section{CHAPTER II: TRAGICAL COMEDY}

Dickens's did not merely value popular entertainment on account of its amusing properties; Dickens viewed entertainment as a highly affective and effective way of distributing social criticism. In his book Dickens and Popular Entertainment, Paul Schlicke describes the covert polemical purpose of Nicholas Nickleby. In discussing Dickens's forward to Nicholas Nickleby in is original serial form, Schlicke writes:

Dickens omits any suggestion of polemical intention. The social satire upon the Yorkshire schools, which constitutes the first and most famous section of the novel, is quaintly alluded to here as 'wander[ing] into fresh fields and pastures new'; and the moral imperatives which drive the plot and propel hero and villain to their respective fates receive no mention at all (34).

Dicken's was seemingly secretive about his use of the novel as social criticism. However, his intentions to expose the horrifying conditions of Yorkshire schools was clear. Claire Tomalin describes Dickens's discreetly planned research trip to Yorkshire prior to composing Nicholas Nickleby:

He travelled to Yorkshire in February 1838 with Browne to see what they could find, pretending to be seeking a school for the son of a widowed friend...Dickens had already constructed in his mind one of his great comic characters, Mr. Squeers, who advertises and comes to London to collect unwanted boys, colluding with those who are keen to be rid of them. (93-4)

Dickens's desire to effect social change in the Yorkshire schools is apparent. But why hide blatant social critique behind the mask of a comedic novel? Why did Dickens opt to use popular entertainment when as a successful journalist he could have easily published forthright criticism? 
Schlicke posits that the novel, and a particularly comedic novel at that, may be the most effective genre to carry Dickens's polemic message, posing that "Entertainment and moral conviction work together as comedy lifts villainy into the sphere of ethical certainties, in which we can laugh heartily at the wickedness because we know it will be defeated" (35). The blatant villainy of Dotheboys Hall, brought to light through the wild comedy of the Squeers family, demands the reader's condemnation of the moral blunders committed at the country school.

This chapter will analyze Dickens's use of tragical comedy for social critique and reform. Tragical comedy becomes an opportune vehicle for entertainment and critique alike in Nicholas Nickleby. Perhaps borrowing from the so called "tragical comedy" of the Punch and Judy Show, Dickens deftly maneuvers between melodrama and ribald drollery through narrative intervention. As Schlicke has suggested, the effective nature of tragical comedy may in part derive from the obvious temporality of good and bad fortune depicted in the novel. In his essay, "A Curious Dance Round a Curious Tree" (co-written with W.H. Hills) Dickens expostulates on "that jocund world of Pantomime, where there is no affliction or calamity which leaves the least impression; where a man may tumble onto broken ice, or dive into the kitchen fire and only be the droller for the accident" (319). In the world of Pantomime, ill fortune is recognizably fleeting. No injury is so great as to cause permanent damage. On the other hand, good fortune is equally transitory. A character may exchange rags for riches (and back again) at any moment. The transitory nature of despair proved attractive for Victorian audiences.

In the same essay, Dickens observes that in Pantomime, "everyone, in short, is so superior to all the accidents of life, though encountering them at every turn, that I suspect this to be the secret (though many persons may not present it to themselves) of the general enjoyment which an audience of spectators, liable to pain and sorrow, find in this class of entertainment" (319-20). The same principle is translated into Nicholas Nickleby. The violence of Dotheboys 
becomes bearable for the reader as comedy mitigates the extremity of abuse. The comedic presentation of would-be tragedy likewise bestows a sense of temporality of the horrible misconduct perpetrated at Dotheboys. This may suggest, to the reader, that social wrongs may be put to an end, and that intervention on behalf of the abused is both possible and necessary. Simultaneously, if, as the previous chapter demonstrated, audiences can aptly recognize themselves in the pantomime figures they witness on stage (and on the page), they may feel a sense of that their suffering, too, is temporary.

The interplay between the tragic and comic enables Dickens to judiciously provide an adequate sense of temporality while still imposing the problematic nature of the suffering experienced by characters such as Smike. Smike's comedy is contextual; his pathos reads comically when he is in the greater world, safe from his former abusers, but tragic when within arm's reach of Squeers. The early scenes featuring Smike as a resident of Dotheboys, portray a heart-wrenching melodrama in which Smike's pathos is suitable to his tragic setting. In voicing his fears to Nicholas, Smike cries, "What faces will smile on me when I die!...Who will talk to me in those long nights! They cannot come from home; they would frighten me, if they did, for I don't know what it is, and shouldn't know them. Pain and fear, pain and fear for me, alive or dead. No hope! No hope!" (98). Smike's fearful musing on his (likely early) death is sobering due to the fact that an early death is imminent and Smike accurately apprehends the reality of his own mortality.

Audience perception of Smike's pathos morphs when his fortunes have changed. Once Smike is on the road with Nicholas, his pathetic musings begin to lose context. When Nicholas suggests that Smike "could be made useful in many ways," on a ship, Smike begins to list possible tasks he may be able to perform, exclaiming, "I could milk a cow, and groom a horse, with anybody" (276). Of course, tending to livestock is not a large need on a ship at sea and 
Nicholas must gently remind him of such. Smike gains a comedic yet loveable pathos once his personal melodrama is juxtaposed against a more prosperous context. Death is no longer a present concern, and so Smike's naïve speech, stemming from a place of trauma, transforms from the tragic to the comic. A similar effect is rendered a moment later when Nicholas offers to take a turn carrying their load. This offer disturbs Smike, who cries 'No! no! Don't ask me to give it up to you" (277). This naturally shocks Nicholas, but what surprises him more is Smike's explanation: “'Let me do something for you, at least,' said Smike. 'You will never let me serve as I ought. You will never know how I think, day and night of ways to please you'" (277). Here, Smike's pathos as the "sad clown" reaches an extreme. His melodrama, which was once an appropriate response to his prospects at Dotheboys, is no longer in accord with his contexts, thus transforming Smike into a grotesque comic figure.

Tragical comedy, also referred to as grotesque comedy or the comic grotesque, plays with a balance between the comic and tragic. William Axton notes that "True grotesque comedy thus finds its peculiar effects precisely in the balance of juxtaposition, rather than the reconciliation, of discordant rather than opposite elements. Its play is with the laughable possibilities of discordance, incongruity, disproportion, and incoherence" (31). The constant interplay between oppositional narrative perceptions of the various characters and scenes of the novel effect a nuanced understanding in the mind of the reader. It enables the reader to grasp with a sense of complexity both the clownish nature of the villains and the sober realities of the world in which they live. Axton notes that Victorian theatrical genres "developed the stage use of fantasy as far as possible, these genres participated in the general tendency in the nineteenth century theater toward realism and accuracy in costume, setting, and properties" (23). Dickens also uses "this grotesque mixture of the real and fantastic" in Nicholas Nickleby, thus equipping his audience to perceive a reality that is at once fantastic and sobering. 
Dicken's treatment of suicide has a similarly juxtaposes the real and fantastic, along with the comic and tragic. Suicide comes up four times within Nicholas Nickleby, and while the last mention is cold and terrifying, the first three are shockingly funny. The first reference to suicide portrayed at the very opening of the novel, during the narrative backstory of the Nickleby family. Concerned that he may not be able to properly provide for his family, Mr. Godfrey Nickleby (the grandfather of Nicholas and Kate) considers taking out a life insurance policy and casually "falling from the top of the Monument by accident" (Nicholas Nickleby 2). The narrator confers this information rather glibly, treating it with a comic nonchalance. This may, in part, be due to the fleeting nature of Godfrey's suicidal intention. As soon as Godfrey learns that his brother Ralph has died and left him his property, Godfrey's depressive mood seems disappear. This implies that sorrow is never quite permanent and may disappear as quickly as it came. Simultaneously, it satirizes a life entirely ruled by money. When funds are in short supply, Godfrey seeks the extreme of suicide, which he naively believes will put an end to his family's troubles. Godfrey's monetary concerns, while not permanent, are recurring, and his finances are perhaps not a reliable source of happiness.

The next two mentions of suicide are similarly attached to money. While traveling to Dotheboys Hall, Nicholas's carriage is overturned and the passengers are forced to stop for the night, and so decide to tell stories to entertain themselves. In the story of the Baron of Grogzwig, the Baron, concerned that his funds cannot supply for his growing family, declares "I don't see what is to be done...I think I'll kill myself' (72). However, as the Baron explains his troubles to the Genius of Despair and Suicide, he begins to realize how trivial his troubles are and determines that "nothing is too bad to be retrieved" (75). The Baron's hopeful epiphany that financial troubles may one day disappear enables him to laugh at his former despair, and thus begin to change his life for the better. At last, he dies "not a rich man...but certainly a happy one" (76). 
Just as Victorian audiences of the Pantomime find cathartic hope in the temporality of the strife of burlesque sorrows, the Baron finds that the woe of life may be faced through the recognition that fortune is highly mutable and liable to change. The closing of the tale reinforces the theory posited in Godfrey's suicidal episode: that money, being somewhat ephemeral and unreliable, is not a dependable source of happiness.

This disconnect between money and happiness resurfaces in the latter half of the novel when Mantalini feigns to poison himself (for the seventh time) in attempt to dissuade his wife and her money from leaving him. However, while a lack of funds similarly fuels the suicide attempt, this instance is distinguished from the others because it gains its comedic potential from its lack of legitimacy. Unlike the intended suicides of the Baron and Godfrey, who experience a life-saving change of heart, in this instance there is only a pretense at suicide, and it is this falsity that provides the scene with its humor. The sense of temporality no longer sources from a change in circumstances but in the lack of reality. We know that Mantalini's sorrow is merely feigned; he only cares for the loss of Madame Mantalini's wealth.

The final mention of suicide, being far from comedic, is terrifying and chilling. Of course, part of the terror comes from the permanence of Ralph's suicide. It is not feigned, nor does he change his mind before performing his final act. The greater part of the terror, however, may be found in Ralph's reason for suicide—-his guilt. Ralph's decision to end his life is spurred by the realization that he has killed his own son (Smike) as a result of his greed. Far from coming to despair through a lack of funds, Ralph hangs himself precisely because he had wealth and he valued it above the life of his young son. Perhaps more damning than the guilt of cupidity, however, is Ralph's discovery of the ultimate futility of his wealth, particularly since Nicholas, who has no great riches to speak of, won the affection of his son. As Ralph's mind turns over the events of his life, he spirals further into despair: 
They had all turned from him and deserted him in his very first need. Even money could not buy them now; everything must come out, and everybody must know all. Here was the young lord dead, his companion abroad and beyond his reach, ten thousand pounds gone at one blow, his plot with Gride overset at the moment of triumph, his after schemes discovered, himself in danger, the object of his persecution and Nicholas's love, his own wretched boy; everything crumbled and fell upon him, and he beaten down beneath the ruins and groveling in the dust. (815)

Ralph's despair isn't quite remorseful. Rather, Ralph dreads his own obsolescence, sensing that his constant pursuit of money has been utterly unfulfilling. Far from providing stability and contentment, Ralph's money-making schemes have driven his family (and his own son) from him and cost him more money in the process. Furthermore, his character and secrets have been exposed. As the futility of his life's work dawns upon him, Ralph finds that he can no longer live with himself.

Intention and measure of permanence forge the tragic or comedic lens of the many suicide attempts of Nicholas Nickleby, but narrative presentation likewise provides a key mark of comedy or tragedy. In the first three instances, the narrator is sarcastic, nonchalant, and even festive. In the final suicide, however, the narrator is grave and renders the scene with long and winding prose. The narrator enters Ralph's own mind, allowing the reader to experience his superfluous and confusing final thoughts. The resulting effect is rather disorienting. The narrator ultimately determines the tone of the scene and dictates how a character, in a given moment, should be perceived by the reader. Schlicke claims that is the narrator's judicious dispensing of comedy and tragedy that provides his writing with a sense of reality, stating: "The air of reality depends crucially, of course, on the quality of Dicken's prose style and on his mediating presence as a narrator in the sketches, genially guiding our attention to the scenes of interest and 
pointing out colourful and amusing details" (41). Although Schlicke here speaks of Sketches by Boz, the same concept transfers to Nicholas Nickleby. The narrator nimbly transforms a scene from comic to tragic with a quick change in prose, and in the next moment returns to his previous tone. It is through the narrator, too, that the novel is able to present the comic grotesque, that is, the tragic told with a comic air.

As Schlicke suggests, the narrator's travesty between tragedy, comedy, and tragical comedy bestows a vital sense of reality upon the novel. Axton, too, recognizes the integral nature of these tonal variations, stating "Dickens took some pains to show the rapid alternations between comedy and tragedy in melodrama, for example, are no more violent than those in real life, but that the man in the street is blinded to this fact by his participation in those events, much as an actor is blind to the artifices of the stage because he participates in them" (38). Just as Nicholas, Kate, and Smike experience abrupt changes from plight to fortune and back again in a moment's notice, the real events of life change just as fast. Here, Axton underscores the issue of perception within everyday life; the actor is naturally aware the violent transitions from comic to tragic, but a legitimate participant in the events of daily life may not be so cognizant. Ability to perceive these abruptions determines how the characters of Nicholas Nickleby operate within any given situation. The characters that do acquire vision for such events, like Nicholas, also gain the ability to introduce comedy into the tragedy of life.

This tragical comedy is perhaps most apparent in the scenes featuring the Squeers family and the boys of Dotheboys Hall. Upon Nicholas's arrival, the narrator describes students of the school, noting that "The whole were attired in such motely, ill-sorted, and extraordinary garments, as would have been irresistibly ridiculous, but for the foul appearance of dirt, disorder, and disease, with which they were associated" (90). Here the liminality between the ridiculous and the foul is apparent. The line itself between the comic and the tragic is rather thin and easily 
traversed, and furthermore reflects the similarities between melodrama and pantomime. Like Smike's mobility between tragedy and comedy, the plight of the boys can be perceived as comic or tragic depending on the context in which they are presented. Comedy occurs in images of incongruity, when word, gesture, or general presentation is discordant with the contexts in which it appears.

The comic grotesque reaches its height when the incongruity of tragedy and comedy is most extremely pronounced. This occurs most notably within the Wackford Squeers and his family. The Squeers family finds pride and amusement in the abuse of others. When young Wackford expresses his future intentio to cane students once he inherits the school, the narrator states that "It was a proud moment in Mr. Squeers's life, when he witnessed that burst of enthusiasm in his young child's mind, and saw in it a foreshadowing of his future imminence. $\mathrm{He}$ pressed a penny in his hands and gave vent to his feelings (as did his exemplary wife also) in a shout of approving laughter" (101). The absurd pride and joy that Mr. and Mrs. Squeers feel at the mention of young Wackford's violent aspirations assumes its humor precisely from the surprising approbation of evil. The violent tendency isn't just lauded in young Wackford, but in Mrs. Squeers as well. Once Mrs. Squeers proclaims that she "hate[s] [Nicholas] worse than poison," Mr. Squeers compliments his wife, assuring her "If you dislike him, my dear...I don't know anybody who can show dislike better than you" (102). Discordance and absurdity give the violent and tragic a comedic glow. Furthermore, the audience must perceive the comedy through their recognition that the violence committed by the Squeers family is wrong. The joy the Squeers family take in evil must be found illogical in order for the comedy to succeed. Dickens places a high trust in his audience to recognize the wrongdoing of the Squeers family without the aid of narrative disapproval. This realization is, perhaps, helped along by the illogical pedagogy of Wackford Squeers. In explaining the curriculum used at Dotheboys, 
Wackford states:

We go upon the practical mode of teaching, Nickleby; the regular education system. C-lea-n, verb active, to make bright, to scour. W-i-n, win, d-e-r, der, winder, a casement. When the boy knows it out of the book, he goes and he does it. It's just the same principle as the use of globes. (92)

Squeers's illogical pedagogy, combined with the absurd love which the entire family has for their own violent ways, helps the reader to arrive at the conclusion that evil is in itself illogical, and therefore has no justification in the world. In this way, incongruity achieves both humor and social critique.

As discussed in the previous chapter, Squeers is far from the only character in the novel to enact violence. Nicholas himself experiences several moments of explosive violence and although his wrath is not random, as we see with Squeers, it is a regularly occurring phenomenon throughout the novel. The violence perpetrated by Nicholas is carnivalesque in nature; although it may have a single physical target in a given moment, its emotional target is much larger. In Rabelais and His World, Mikhail Bahktin suggests that in carnivalesque displays of violence, "thrashing and abuse are not a personal chastisement but are symobolic actions at something on a higher level, at the king" (197). Although Nicholas is angry with Squeers and the conditions at Dotheboys Hall, his actions are not merely aimed at Squeers. Rather, Nicholas's thrashing of Squeers is aimed at Ralph, the man who placed him in Dotheboys Hall in the first place. The thrashing of Mulberry Hawk bears this dual target as well. Nicholas's fury is not simply at Hawk, but at his uncle for placing Kate in such a terrible situation.

Both Nicholas's placement at Dotheboys and Kate's subjection to sexual harassment occurred at the hands of Ralph, and when Nicholas avenges these actions through beating Squeers and Hawk, Ralph understands that these actions are in fact a rebellion against himself. 
The first and last abuse violently addressed in the novel is the abuse continually enacted against Smike. Nicholas indirectly addresses this abuse through caning Squeers, but it is Ralph who takes the final revenge for Smike's abuse upon himself. Once Ralph realizes that he has set these series of abuses into motion (which ultimately return on himself) he enacts the novel's final act of violence.

Louisa Jones notes that violence of Commedia origin, much like the violence witnessed at the circus and pantomime, "is at times like carnival violence, linked to patterns of ritual sacrifice and rebirth, even in the $19^{\text {th }}$ century pantomime" (21). The violence enacted by Nicholas (and finally by Ralph himself) serves to oust the old generation, Ralph, of power, and make a place for the new generation, Nicholas and Kate, in the world. Bahktin further explains this concept: "Every blow dealt to the old helps the new to be born. The caesarian operation kills the mother but delivers the child. The representatives of the old but generating world are beaten and abused. Therefore, the punishment is transformed into festive laughter" (206). Here too, lies another source of grotesque comedy within violence within Nicholas Nickleby. The abuse is transformative and delivers the new generation, representative of socially empathetic and less greed driven population. Ralph's death, then, becomes representative of the death of an older, covetous generation that values money and industry over the lives of individuals.

In directing their violence against representatives of the old generation, the new generation, implementing the thrashing, must reveal the treachery of the old. Bahktin states that "Abuse reveals the other, the true face of the abused, it tears off his disguise and mask. It is the king's uncrowning" (197). Violence enacted against the representative of the old generation reveals its formerly hidden misdeeds. Ralph, the guardians of the children at Dotheboys, and the members of the United Metropolitan Improved Hot Muffin and Crumpet Baking and Punctual Delivery Company all mask their greed with the pretense of morality, feigning concern for the 
virtue and wellbeing of these in their care. Squeers performs this mask quite frequently. The narrator informs its audience that:

popular rumour in the neighborhood asserted that Mr. Squeers, being amiably opposed the cruelty to animals, not unfrequently for boy consumption the bodies of horned cattle who had died a natural death; possibly he was apprehensive of unintentionally having devoured some choice morsel intended for the young gentlemen. (83)

Squeers frequently claims to be teaching his students sound morals to disguise his actual pennypinching motivations. Squeers's masked self is performed so often that he actually takes his moral pretense for genuine virtue. In describing the difference between Squeers and his wife, the narrator reflects: "Mrs. Squeers waged war against the enemy openly and fearlessly, and that Squeers covered his rascality, even at home, with a spice of his habitual deceit; as if he really had a notion of someday or other being able to take himself in, and persuade his own mind that he was a very good fellow." (88) Squeers is, in fact, blind to his own rascality. His constant performance has allowed him to believe that his morals may, in fact, be legitimate. The unmasking committed in Nicholas's act of violence, however, reminds Squeers and the surrounding community that the schoolmaster's morals are a mask for various money-making schemes, and that the abuse he subjects the young boys to is both serious and unwarranted.

The act of violent "unmasking" not only reveals Squeers to the community but reveals Squeers (at least in the moment) to himself. Speaking of the reality that Dickens saw in Pantomime, Axton muses, "in real life men are unable or unwilling to perceive in its true colors the histrionism of human actions owing to their participation in the conventions of social intercourse. In real life men are 'the busy actors, instead of passive lookers-on, which makes vast difference.' And like actors, who are blind to the "violent transitions and abrupt impulses of passion 
or feeling,' men are equally incapable of seeing the essentially grotesque extravagance of their ordinary behavior. (41-2)

Many characters in Nicholas Nickleby are blind to their own behavior and ultimately unable to recognize their own clownish and exaggerated dispositions. Squeers has deceived himself into the presumption that at heart, he may be "a very good fellow." Similarly, Ralph has convinced himself that his way of life really is most prudent, that any complaint he might hear from his family is just emotional bosh and that, at the end of the day, "there was nothing like money" (3). Just as Nicholas's violence "unmasks" Squeers to himself and to the community, Ralph's suicide finally unmasks himself, a guilty and foolish Pantaloon, guilty to his greatest crime, hanged "in the very place to which the eyes of his son, a lonely desolate little creature, had so often been directed in childish terror, fourteen years before" (819). In this final act of self-unmasking, Ralph confirms himself as the perpetrator of the primary abuse against Smike.

If, as demonstrated both within "The Pantomime of Life," and Nicholas Nickleby "all the world is a stage" then the novel, and the series of constant unmaskings, may serve to reveal the readers' own clownish tendencies to themselves. Jones claims that "Different writers confer different disguises on their heroes with differing emphasis: common, however, is the desire to draw the reader's or viewer's attention to his own part in the grotesque twinship, to point out to the bourgeois that he, too, is a clown" (25). Nicholas Nickleby contains figures such as Ralph, Squeers, Mulberry Hawk, Mantalini, and a throng of other characters who become victims of their own self-deception. A final incongruity then, between the self-deceived and the self-aware such as Nicholas and Kate, paint yet another layer of humor upon the novel. The following chapter will explore this final type of incongruity and Dickens's value of comic perception. 


\section{CHAPTER III: CARNIVAL LAUGHTER}

Dicken's begins Nicholas Nickleby not with an introduction to its protagonist, or even its antagonist, but with Godfrey Nickleby, father of Ralph and grandfather of Nicholas. It is Godfrey, and his perception of life, and Godfrey's wife's perception of Godfrey which she passes down to their children, that sets the plot in motion. The account of Godfrey's life shapes Ralph's villainy and Nicholas's heroism alike. The novel opens with a rather depressed Godfrey, who is apparently running low on funds and friends:

It is extraordinary how long a man may look among the crowd without discovering the face of a friend, but it is no less true. Mr. Nickleby looked, and looked, till his eyes became sore as his heart, but no friend appeared; and when, growing tired of the search he turned his eyes homeward, he saw very little there to relieve his weary vision.

\section{(Dickens 1-2)}

Godfrey experiences a weariness that, while induced by his low income, is ultimately caused by his lack of companionship, and a lack of a congenial sense of familiarity in his surroundings. He finds nothing to lift his spirits. Godfrey lacks, in a sense, amusement.

Amusement, in its wide variety of forms, provides a vital sense of familiarity to its audience due to its verisimilitude. Amusement holds the potential to provide its audience a framework with which to understand the world and scenes that they occupy. This chapter will examine the practical utility of amusement in the lives of the characters of Nicholas Nickleby through the reception of story, interaction with theatre, and their ability to amuse themselves through their recognition of the carnivalesque in common life. Furthermore, this capacity for self-amusement, demonstrated in the tendency towards laughter, will be examined in relationship to its potential in creating a socially just and empathetic community. 
Despite the Victorian fear that amusement indulged its audiences in amoral and unproductive laughter, amusement offers its audience more than mere levity. Godfrey’s unrelenting weariness requires something more than sober recreation in order for it to finally subside:

A painter who has gazed too long upon some glaring colour, refreshes his dazzled sight by looking upon a darker and more somber tint; but everything that met Mr. Nickleby's gaze wore so black and gloomy a hue, that he would have been beyond description refreshed by the very reverse of the contrast. (2)

This narrative commentary provides two interesting insights. First, that a balance of dark and light, the tragic and the comic, is necessary for healthy perception and mentality. Second, that some, such as Mr. Godfrey Nickleby, have received such an unbalance of one, namely the gloomy and tragic, that something bright and humorous would completely change their outlook on life. Amusement holds the potential to provide both extremes of light and dark to its viewers. The tragical comedy witnessed in amusement deals out extremes, introducing balance into the renewed perception of the audience member.

Godfrey is merely the first character in the novel to be plagued by an overly gloomy perception. On Nicholas's journey to Dotheboys, the carriage overturns and its passengers, finding they must stop for the night, decide to entertain themselves by telling stories. In the last chapter, I examined the portrayal of suicide within "The Baron of Grogzwig," demonstrating its grotesque comedy of incongruity. While the tale is a wonderful example of tragicomedy, it affords more than mere amusement to its listeners, as does the first tale told, "The Five Sisters." After one passenger tells a particularly somber tale, he justifies his choice in tone claiming that, "It is a tale of life, and life is made up of such sorrows" (66). He feels that a tale which accurately represents life must be entirely sorrowful, since, by his perception, life itself is one 
continuous tragedy. This opinion, however, is challenged by another "merry-faced passenger" who insists that, "There are shades in all good pictures, but there are lights too, if we choose to contemplate them" (66). Light-heartedness, good humor, and hope, according to this merry passenger, is a matter of choice. The light parts of life must be contemplated along with the shades in order for life to be perceived accurately, because the two co-exist together. This merry faced passenger, in his statement, also passes a commentary on art. Not only does life possess both light and dark, but a "good picture" must as well. Both are absolutely vital to a life welllived.

The necessary choice to contemplate the good along with the bad is prominent across Dickens's writings. Paul Schlicke notes that:

The mood of amusement in Sketches by Boz is controlled by the principle that the fascination of everyday scenes has only to be recognized to be enjoyed. Pleasure is thus dependent on the eye of the beholder; whether he be participant, spectator or entertainer himself, a person's enjoyment arises from his own readiness to respond to the abundance and variety of stimuli available. (40)

Dickens saw a world filled with comedic potential, a world that could be enjoyed despite (or perhaps even because of) the trouble that also plagues it. Nicholas Nickleby details its protagonist's journey of perception, a perception that begins with a naïve optimism, transitions to a disillusioned gloom, and finally arrives at a disposition of amusement that allows Nicholas to actively pursue the life he desires for his family and himself.

The last chapter explored the use of the comic grotesque within Nicholas Nickleby. Nicholas's defeat of Squeers is a necessary process that induces the birth of a new, just social order and the death of the old authority. While laughter is a natural result of the comic grotesque, it also acts as weapon to disarm and defeat the old oppressive forces. According to Mikhail 
Bahktin, in carnivalesque humor, we find "the defeat of fear presented in a droll and monstrous form, the symbols of power and violence turned inside out, the comic images of death and bodies gaily rent asunder. All that was terrifying becomes grotesque" (91). The defeat of the once terrifying Squeers, somewhat monstrous in both his violence and in form, represents the defeat of the former fear he once held over Dotheboys Hall.

This is, perhaps, the first instance in which Nicholas recognizes the potential power of the carnivalesque; he does not, however, identify his actions as comic in his moment of fury. That power of recognition lies with John Browdie, who roars with laughter at the news that Nicholas has beaten Squeers, mirthfully crying, "Beatten the schoolmaster! Dang it, I loove thee for't" (159). Browdie's laughter audibly acknowledges the amusing nature of a once terrifying situation. It likewise celebrates the comic dissolve of Squeers's authority. The comic, and the act of laughter, therefore holds social potential. Eigner affirms the social utility of the comic within Dickens's writing, positing, "It takes the Dickens pantomime much more seriously [than Shaw], seeing in it the essential pattern of Dickens's comedy, the basis for his psychological insights and his social vision, as well as the modus operandi of his aesthetics" (8). The comedy of the pantomime, found in life as well as the stage, enacts Dickens's social vision. Axton observes the potential that the pantomime of life holds for social critique and action, stating, "Its intention, then, is to achieve that helpless laughter at the human condition in all its manifold antic life; but in its darker vein, it may seek a recognition of the sinister or macabre elements which lie concealed just beneath the commonplace surface of things" (30). The theatre of life has the dual ability to provide amusement and unmask the treachery that may be occurring in common life. Laughter unmasks the villainy of the commonplace but refreshes the spirit in the process. The dual quality of the comic and tragic of the commonplace can be communicated with an audience who may not be able to immediately perceive it themselves through story. 
Just as the passengers of the carriage choose to tell stories that reflect their worldview, the stories told in the novel similarly contribute to the construction of their listener's worldview. Axton observes that "Victorian audiences were thus to a particular degree involved with that willing suspension of disbelief—as well as belief—which constitutes theatrical illusion. Indeed, they were simultaneously called upon to lose themselves in imaginative identification with the personages and events on stage as if they were real" (26). Audiences could see themselves in the stories of the stage and thus could, consciously or unconsciously, incorporate the forms presented to them into their own experiences. Deborah Vlock takes this notion further, stating, "Notwithstanding the nineteenth century's powerful antitheatrical sentiment, performative tropes and gestures were received as examples of realism, and the social world borrowed its paradigms from the stage" (59). Not only would an audience readily accept the potential reality of the tales of the stage, but would borrow from them, incorporating paradigms for behavior and action into their own social circles.

This tendency is demonstrated numerous times throughout Nicholas Nickleby in the individual reactions of the characters to the stories that they hear. Ralph and Nicholas Sr., from the time of their childhood had often heard, from their mother's lips, long accounts of their father's sufferings in his days of poverty, and of their deceased uncle's importance in his days of affluence: which

recitals produced a very important impression on the two: for while the younger, who was of a timid and retiring disposition, gleaned from thence nothing but forewarnings to shun the great world and attach himself to the quiet routine of a country life, Ralph, the elder, deduced from the often-repeated tale the two great morals that riches are the only true source of happiness and power, and that it is lawful and just to compass their acquisition by all means short of felony. (3) 
The stories that young Ralph and Nicholas Sr. are told of their father and uncle are far from innocuous; they shape the entirety of their lives. Nicholas Sr. finds it best to be content with a small a country existence, far removed from the concerns of the city and its monetary pressures. Ralph, on the other hand, is impressed with the notion that only money can furnish contentment, and thus "always wound up these mental soliloquies by arriving at the conclusion, that there was nothing like money" (3). The tales of Ralph's childhood transformed him into a Pantaloon and a villain.

Nicholas is similarly formed by the stories that he is told. Stories comprise the first part of Nicholas's transformation from a naïve adolescent into a perceptive adult, and the tales that Nicholas hears on his journey to Dotheboys both foreshadow and prepare him for the events that await him on his travels. The first tale told, "The Five Sisters of York" is a somber story of experience. Near the opening of the tale, its speaker (the grey-haired man) exclaims, If while our bodies grow old and withered our hearts could but retain their early youth and freshness, of what avail would be our sorrows and sufferings! But, the faint image of Eden which is stamped upon them in childhood, chafes and rubs in our rough struggles with the world, and soon wears away: too often to leave nothing but a mournful blank reimagining. (59) The grey-haired man, much like Godfrey Nickleby, is wearied with a dark vision of the world. In his view, childhood innocence is brief and quickly overcome by the "rough struggles with the world." Nicholas arrives at this frame of mind during his time at Dotheboys. Rapidly realizing the undue trust that he has placed in society at large, Nicholas grows increasingly "so depressed and disgraced by the consciousness of his position, that if death could have come upon him at that time he would have been almost happy to meet it" (97). While in the midst of Dotheboys, Nicholas lacks humor, overwhelmed by the depravity he had not previously realized existed in the world. 
The realization of the existence of sorrow, while rather uncomfortable, is a necessary aspect of Nicholas's transformation. Just as the narrator informs its audience that "A painter who has gazed too long upon some glaring colour, refreshes his dazzled sight by looking upon a darker and more somber tint," Nicholas's life has thus far has been glaringly bright, and while the somber tint of Dotheboys is far from refreshing, it does adjust his vision. It enables Nicholas to perceive the villainy of his uncle as well as the need for social reform.

The second tale, "The Baron of Grogzwig" presents an alternative approach to "the rough struggles of life." As discussed in the previous chapter, this yarn follows the Baron von Koëldwethout through his depression, near suicide, and eventual renewal of life. The Baron's name, pronounced "cold-without," signifies his icy perception of the world. The Baron initially finds himself attempting to win a woman whose father must be convinced to give his blessing through threat alone -a situation similar to the one Nicholas will one day find himself in with Madeline Bray. In fact, the Baron proclaims that if the lady's father will not give her hand in marriage, he will cut off his nose (perhaps foreshadowing Nicholas's nose-pulling challenge with Lenville). Once he decides that he must kill himself, the baron is visited by the Genius of Suicide and Despair.

The Genius prods the Baron towards suicide, and is rather successful in this pursuit until he accidentally causes the Baron to laugh by describing another suicide: " 'Going to kill himself because he has too much money!' exclaimed the baron...'Ha! ha! that's a good one"' (75). This laughter causes the baron to reexamine his situation with a fresh mind. The narrator notes that "this was the first time the baron had laughed for many a day long" (75). In his attempt to retrieve the conversation, the Genius inadvertently causes the baron to see the ridiculousness of his own situation: "the baron stopped his hand all of a sudden, opened his eyes wide, and looked 
as if quite a new light had come upon him for the first time" (75). A brief moment of comedy changes the Baron's entire perception of the world and of himself.

Unlike the first story, the second blends comedy and tragedy, thus emphasizing the necessity of the ability to perceive both the comic potential in the world. The tale furthermore promotes the capacity for self-mockery, given that the baron is able to laugh at himself. While the tale may not bear immediate effect upon Nicholas, as his travels present him with situations which mimic those of story (the initial punch-like violence of the baron, a melodramatic love affair, nose related threats, etc.), the story seems to provide Nicholas with a mental paradigm to understand the world around him, and like the baron, gain the ability to laugh at the world instead of giving into despair.

The act of personal storytelling becomes an important aspect of the novel as well. Nicholas and Smike must tell their own life stories to each another. Nicholas helps Smike to recover his own narrative, slowly piecing together the scattered memories of his past. Nicholas, "with assumed carelessness" asks questions that spark memories of the past (278). This recovery seems to be therapeutic for Smike and helps him to confront his trauma. In assuming a careless manner, Nicholas again begins to develop a double self. Previously, he wore his true feelings on his sleeve. By the time of his arrival in Portsmouth, not only has Nicholas transformed from his former naïve self, but adopted an official mask, "Mr. Johnson.”

Smike seems to benefit from learning Nicholas's life story as well (380). Smike is eager to learn of Nicholas's family, his situation, and the progression of his life. Given Smike's lack of experience in the world, and the unusually dark nature of his circumstances, Nicholas's life story presents an opportunity for Smike to construct an understanding of healthy familial relationships (within Nicholas's more immediate family) and obtain a more complex social understanding. The act of listening to Nicholas's personal history with his uncle Ralph allows for Smike to 
occupy his mind with sorrows that are not his own (although, of course, Nicholas and Smike unknowingly share the same enemy).

The final act of personal storytelling occurs near the novel's close. After learning of his son's death, Ralph remembers a long-forgotten incident from his past:

Ralph called to mind that he had been one of a jury, long before, on the body of a man who had cut his throat; and that the man was buried in this place. He could not tell how he came to recollect it now, when he had so often passed and never thought about him, or how it was that he felt an interest in the circumstance, but he did both. (814)

The recollection of this memory, which Ralph replays several times, occurs right before Ralph's own suicide. Perhaps it is this memory, replayed over and over, that prompts Ralph to take his own life.

Painful memories, however, are not always so destructive. For Smike and Nicholas, the painful past finds cathartic expression in the act of remembrance. The merry faced-gentleman expresses a thought on past-reflection that aptly describes the experiences of Nicholas and Smike:

To remember happiness which cannot be restored is pain, but of a softened kind. Our recollections are unfortunately mingled with much that we deplore, and with many actions which we bitterly repent; still in the most chequered life I firmly think there are so many little rays of sunshine to look back upon, that I do not believe any mortal (unless he had put himself without the pale of hope) would deliberately drain a goblet of waters of

Lethe, if he had it in his power. (67)

For Nicholas and Smike, the act of personal storytelling softens the trauma of the past, as painful as it may be. The act of self-expression, along with the eventual softening of past pain, allow 
Nicholas and Smike to build a new life for themselves and attempt to redefine the ways in which they fit into the world.

It is no coincidence that the pair learn to voice their past trauma and re-construct new identities as they begin their theatrical career. The pantomime of the $19^{\text {th }}$ century grew out of Romantic thought, which valued carnivalesque subversion and revelry. Bahktin claims that "The Romantics developed a broadened concept of reality and lent a great importance to time and to historic becoming" (124). As Nicholas and Smike begin to re-envision their own selfhood and surroundings, they inhabit the world of the theater, in which reality is broadened and imbued with a significance grasped by an audience who at once experiences the play in and out of time, being simultaneously involved in the suspension of disbelief and removed as observer. This experience demonstrates how a sense of self might be broadened, and how Nicholas might at once play the active participant and amused observer of the daily scenes of life.

Bahktin furthermore explains that "Thanks to this concept, [the Romantics] strove to see in a masterpiece much more than that which appeared on the surface. They sought to discover the signs of the future, the embryo, the shoots, the seeds, the prophecies, and the revelations" (124). Nicholas, in particular, begins to look beyond the surface as he enters the wider world. The first sign of Nicholas's acceptance of a complex and multilayered reality is demonstrated in his adopted duplicity of identity. In taking the name "Mr. Johnson" upon himself, Nicholas adopts a mask, a secondary performative identity that can operate somewhat independently of his true feelings. While Nicholas adopts this pseudonym before the advent of his acting career, the performative nature of the mask is not fully realized until he takes to the stage, influenced by the inherent duplicity of the actors around him.

The various identities present on stage become available to members of Crummles company, thus resulting in that duplicity. Schlike describes this phenomenon in Dickens and 


\section{Popular Entertainment:}

Among the characters, Crummles's players are professionally engaged in the theatre, and their disposition to turn every opportunity into an excuse for acting reveals histrionic sensibility as their essential trait. When Mr. Lenville undertakes to pull Nicholas's nose before the assembled company, when, with 'heart-rending' sobs, Mr. Crummles personates the bride's father at Miss Petowker's wedding, the artifice of dramatic performance spills off the stage into private life, and the absurdity of their posturing serves their enjoyment, and ours. (50)

The masks inhabited by the actors on stage become adopted identities in their everyday life. Lenville, a tragedian, presents "Nicholas to that expression of face with which, in melodramatic performances, he was in the habit of regarding tyrannical kings" (385). Likewise, Folair the pantomimist, in communication with Lenville, ponders how he might "give such an account of his proceedings as he might think best calculated to carry on the joke" (384). Nicholas witnesses these spectacles that blend stage and reality and finds that the available actions and deportments for daily interaction may be extended to include those of the stage.

Nicholas's performance of dual identity, as well as his use of theatrical action, culminate in his confrontation with Lenville. Upon reading Lenville's invitation "for the purpose of having his nose pulled in the presence of the comedy," Nicholas experiences somewhat conflicting emotions:

Indignant as he was at this impertinence, there was something so exquisitely absurd in such a cartel of defiance, that Nicholas was obliged to bite his lip and read the note over two or three times before he could muster sufficient gravity and sternness to address the hostile messenger. (381) 
Here, Nicholas is faced with competing states of mind: Indignance and amusement. The sense of amusement seems stronger than any offense that Nicholas feels, and yet he makes the conscious decision to privatize his amusement. Nicholas chooses to perform offense as Mr. Johnson while secretly delighting in the absurdity as Nicholas. This secret delight, however, renders the public act of offense effective.

Nicholas's recognition of the inherent absurdity of Lenville's letter prompts him to respond in an equally absurd manner. When Folair explains to Nicholas that he must either respond by swearing peace or by allowing his nose to be pulled, Nicholas poses a third option suggesting, "but suppose I were to turn the tables, and pull his nose, what then?" (383). Such a proposition catches Folair off guard, given that Mr. Johnson is "always so mild spoken" (383). Since Nicholas's offense is feigned and Lenville's genuine, Nicholas is able to act subversively. Schlicke observes that:

The notion that Nicholas belongs 'naturally' among the players takes us to the heart of their significance in Nickleby...Although he is indignant at Lenville's impertinence of offering to pull his nose, Nicholas enacts a scenario of his own when he defies the tragedian before the assembled company and knocks him down. His bow to the spectators after the confrontation shows clearly his consciousness that the action has been a performance. (76)

If Lenville unconsciously borrows from melodrama, Nicholas consciously borrows from pantomime, knocking his enemy down. Nicholas has become an actor.

The ability disguise himself and perform an alternative identity signifies Nicholas's adoption of carnivalesque behavior. Bahktin mentions that "one of the indispensable elements of the folk festival was travesty, that is, the renewal of clothes and of the social image" (81). In posing as Mr. Johnson, Nicholas has the opportunity construct his class identity as he chooses. In 
associating himself with a collection of actors, Nicholas places himself in a lower cast. However, since "Johnson" is merely a mask, Nicholas maintains the possibility for mobility, and is at any time capable of shedding this performative identity and reverting back to Nicholas Nickleby, son of a gentleman. Schlike notes that Nicholas "is concerned to preserve his dignity as the son of a gentleman, and has more than a touch of snobbery to him" (82). Nicholas's travesty exhibits a temporary partaking of lower-class life, all the while preserving the gentile identity which may be accessed at any time.

Despite this vital gift of duplicity bestowed upon Nicholas by Crummles and his troupe, some critics express the concern that Dickens and Nicholas fail to emphasize the value of the company of actors. Schlike poses the concern that Crummles's company plays no specific moral role in the novel and bemoans the lack of credit given to Crummles laudable qualities, asserting that, "Neither Nicholas nor Dickens gives full credit for excellence of his personal qualities, and it is a disturbing limitation of the novel that a lack of polite airs should be held against the manager" (82-3). It is, perhaps, true that Nicholas favors his gentlemanly identity over his thespian mask, and furthermore prefers a socially respectable career working for the Cheryble brothers over a career in the theater (however successful he may be as an actor and a playwright). However, Schlicke possibly misses the important function that Crummles and his company play in Nicholas's life. The acting troupe equips Nicholas with the capacity for amusement, teach him that identities may be performed, and that the comedic possibilities of the stage may be utilized in order to challenge oppressive hierarchies.

Nicholas's desire to laugh at Lenville's letter signifies his successful transformation into the carnivalesque Harlequin of the pantomime. His amusement becomes a weapon equal to that of his physical strength. Combined, Nicholas's amusement and physical retaliation allow him to 
overthrow Squeers and finally, his Uncle Ralph. Bahktin theorizes that laughter has a peculiar transformative power:

Laughter has a deep philosophical meaning, it is one of the essential forms of the truth concerning the world as a whole, concerning history and man; it is a peculiar point of view relative to the world; the world is seen anew, no less (and perhaps more) profound than when seen from the serious standpoint. Therefore, laughter is just as admissible in great literature, posing universal problems, as seriousness. Certain essential aspects of the world are accessible only to laughter. (66)

Here lies the heart of Dickens's use of amusement for social vision. Those who are amused find themselves with wider access to the world, and the audience member who is amused will mentally be able to perceive the world as it truly is.

The sheer power of laughter is first demonstrated in the "Baron of Grogzwig." When the Baron laughs at news that a man once killed himself because he had too much money, the Genius of Suicide and Despair begs him to refrain from laughing "Because it gives [him] pain all over" (75). Despair cannot survive laughter. The narrator notes that "this was the first time the baron had laughed for many a day" (75). Laughter renews the baron and provides him with a strength that he did not previously possess. Armed with laughter, the baron is able to withstand the Genius of Suicide. In fact, "a joke, without any figure of speech is the death of [the Genius of Suicide]" and when the baron laughs "loud and boisterously" the Genius kills himself (76). The baron's laughter kills despair.

Laughter plays an essential role in displacing fear within Nicholas Nickleby. As Nicholas moves throughout the novel, laughter repeatedly dispels the spell that the gravity and seriousness of despair holds over the characters. Bahktin describes the inevitable estrangement from fear that must take place in carnivalesque writings, insisting that "fear can only enter a part that has been 
separated from the whole, the dying link torn from the link that link that is born. The whole of the world is triumphantly gay and fearless" (256). In the world of carnival, fear can only survive in characters who are a part of the dying, old authority, and furthermore, the birth can only occur by result of tearing away from the dying link. As Nicholas transforms into the comedic Harlequin, the communities that he moves within are transformed from landscapes of seriousness, and even despair, to spectacles of laughter.

The first instance where Nicholas's presence transforms despair into laughter is at Dotheboys Hall, when Nicholas himself is still rather depressed. Fanny Squeers flirts with Nicholas in front of the young students, causing the two to bump heads when both attempt to pick up Fanny's pen, at which point, "five and twenty little boys laughed aloud: being positively for the first and only time that half year" (104). Like the baron of Grogzwig, the boys have not laughed in an extremely long time; their lives have been ruled by despair. The small instance of laughter changes the entire atmosphere of the room, at least temporarily. However, Nicholas does not yet embrace carnivalesque laughter at this point in the narrative, being rather prone to taking himself too seriously, a tendency that is brought to light by John Browdie.

John Browdie is a prime example of a disposition of amusement that defeats fear. Early in the novel, when Nicholas is playing cards with John, Fanny, and Matilda, Nicholas initially finds himself frustrated at John's tendency to poke fun at the conditions of Dotheboys Hall. When John jokes that Nicholas will "be nowt but skeen and boans" if he stays employed at the school, Nicholas initially scorns the comment suggesting that John speaks facetiously (109). John continues with his joke, however, and, while describing the last lean teacher to work for Squeers "laughed until he found it necessary to apply his coat cut to his eyes" (110). At this point, Nicholas perceives himself and his situation rather gravely, and cannot see the potential humor in. Therefore, Nicholas finds John's constant jesting rather offensive. Meanwhile, he fails 
to realize that John Browdie may be the only person he has met to not fear or bow to the schemes of Squeers. Axton finds that "comedy innocuously annihilates dignity and greatness, especially if they are falsely assumed, on some secure basis of real values; but burlesquerie in effect aims to do away with familiar footholds of tradition and convention-even with dramatic credibility" (32). Browdie's laughter diminishes both the greatness of Squeers and the early Nicholas alike. The Yorkshireman's common status only augments the power of his laughter. Refusing to believe in the assumed greatness of those in power, Browdie equalizes the social network that he inhabits.

Browdie demonstrates the use of carnivalesque laughter in the defeat of fear and its subsequent dismantling of hierarchy. Bahkitn suggests that laughter "overcomes fear, for it knows no inhibitions, no limitations" and furthermore is "the defeat of divine and human power, of authoritarian commandments and prohibitions, of death and punishment after death...This truth was ephemeral; it was followed by the fears and oppressions of everyday life" (92). John finalizes Nicholas's transformation into a Harlequin figure through his jubilant recognition of Squeers carnivalesque overthrow. Upon hearing the news that Nicholas has beaten Squeers and fled Dotheboys, Browdie exclaims, "Beatten the schoolmeasther! Dang it, I love thee for't” and "laughed and laughed again—so loud that the echoes, far and wide, sent back nothing but jovial peals of merriment" (159). Browdie's laughter transforms the terror and gravity of Dotheboys into festive merriment, finally dispelling the fearful reign of Squeers.

The fact that Squeers has a deformity further establishes the festive nature of his defeat. Bahktin expresses that "we always find in them the defeat of fear presented in a droll and monstrous form, the symbols of power and violence turned inside out, the comic images of death and bodies gaily rent asunder. All that was terrifying becomes grotesque” (91). Squeers’ 
"monstrosity" presented in his missing eye, demonstrates the grotesque nature of his defeat. As Nicholas beats Squeers with his own cane, the once terrifying figure becomes a monstrous joke - but only once it is recognized as such by John Browdie.

Communal participation in festive subversion is necessary for the suspension of authoritarian power. Describing the necessity of social consciousness in cultural renewal, Bahktin states:

Man experiences this flow of time in the festive marketplace, in the carnival crowd, as he comes into contact with other bodies of varying age and social caste. He is aware of being a member of a continually growing and renewed people. This is why festive folk laughter presents an element of victory not only over supernatural awe, over the sacred, over death; it also means the defeat of power, of earthly kings, of earthly upper classes, of all that represses and restricts. (92).

In order for the hierarchical subversion of festive laughter to take place, Nicholas must first envision himself as a member of a community. While Nicholas initially recognizes himself as a member of his own insular family unit, he approaches Dotheboys as an individual. While in this frame of mind, Nicholas perceives the school as a static community under the impenetrable authority of Squeers.

Nicholas's individualistic approach to the community at Dotheboys proves problematic; as a mere bystander Nicholas finds himself complicit in the abuse enacted by the Squeers family. Nicholas discovers that "being there as an assistant, he actually seemed—no matter what unhappy train of circumstances had brought him to that pass - to be the aider and abettor of a system which filled him with honest disgust and indignation" (97). Nicholas finds that his own troubles cannot excuse him from participating in the community that he inhabits, and that, furthermore, non-participation merely equates to compliance and the reinforcement of an abusive 
system. Realizing his necessary participation in the community, Nicholas eventually chooses to act on behalf of Smike, with whom he has developed a strong bond. Once Nicholas has gained this social consciousness, the community at Dotheboys becomes dynamic, and the hierarchy of the school breaks down (at least, temporarily, as in carnival time). John Browdie further acts as an essential member of the renewed community through his constant amusement. His celebratory approbation of Squeers's defeat renders the former reign of terror null and void. Since Squeers is now thoroughly amusing, he has lost the power of fear that he once held.

Communal participation in festive laughter gains further importance when considered in Dicken's social use of the novel. The reader of the novel becomes an active participant of the amusement, unmasking Squeers, Hawk, and Ralph through their own laughter. Dickens's choice to present social commentary through an amusing medium allows his readers to participate in carnivalesque subversion and gain a disposition of amusement themselves. The novel itself wavers between pantomime and melodrama, dealing out scenes that intermittently awaken laughter and melancholy. While there are great festive bursts of comic overthrow of hierarchy, there are likewise moments of grave sobriety, when the sorrows of various characters, such as Smike, become prominent. This is because, as Bahktin observes, "the feast was a temporary suspension of the entire official system with its prohibitions and hierarchic barriers" (89). Therefore, these festive images of hierarchical suspension in Nicholas Nickleby are always temporary. They exist as brief, intense bursts of festivity and eventually subside into the societally ordained routine of Victorian life.

The drama of the novel builds up to such comic bursts of carnival violence, travesty, confusion, and suspension. Likewise, the events that take place in each new location entered by Nicholas culminate in a final burst of festivity that propels him on to each new location. The overthrow of Squeers sends Nicholas onto London, his confrontation with his uncle in London 
delivers him on to Crummles's company, the nose-pulling incident propels Nicholas onto his avenge his sister in London by attacking Mulberry Hawk, and this final event leads him to gather his family and move to a small home, no longer under the care of Ralph, and seek employment with Cheerybles. Tragedy builds to festive subversion and comic overflow, and the cycle continues over and over again.

Nicholas's position with the Cheeryble brothers brings and end to the pantomime "chase scene" that dominates the first half of the novel. Geographically, the story comes to a standstill. However, a few carnival scenes remain: the pantomime rescue of Madeline Bray and the second rescue of Smike from Squeers. The Madeline Bray plot plays an important role in revealing the clownish elements of Nicholas's own character. Thus far, Nicholas lays claim to Harlequin characteristics through his bursts of comic violence that initiate (temporary) social subversion, but Nicholas has yet to reflect Harlequin as a fool in love. After spotting Madeline once, Nicholas falls head over heels in love, and follows Newman Noggs on a mission to her, only to find that Newman has found the wrong girl and that they are hiding in the pantry of a person with whom they have no connection whatsoever.

Although the Madeline plot features none of the comic grotesque of past festive scenes (after all, Mr. Bray essentially just drops dead) it does belong to the socially subversive comedy of carnival. According to Bahktin, "the usual rule and order of life, and especially the social hierarchy were suspended at the wedding feast" (264). The various escapades leading to the marriage of Nicholas and Madeline (as well as Frank and Kate) function as a narrative wedding feast, where "the usual rule and order of life" is suspended. Nicholas acts as a romantic fool, falling desperately in love with a girl he has seen once in his life, Newman Noggs causes mad confusion, identities are confused, evil plans are thwarted, and finally, Madeline's father dies a bizarre and random death as "the dying link torn from the link that is born" (256). The wedding 
feast presents an opportunity for a new type of social revival that manifests itself in the literal birth of a new generation.

The new generation is birthed through the festive exploits of the novel, and likewise, the old generation, representing injustice and sorrow of the past, is of necessity cut off. Thus, two members of the Nickleby family most involved in the sorrowful scenes of the past die: Ralph and his son, Smike. Neither father nor son is able to be finally integrated into the peaceful future of the Nickleby family. This inability to integrate, while expected with Ralph, is perhaps surprising with Smike. After all, the rest of the family do take him in, attempt to make him a part of their home, and desire a future for him and with him. Smike, however, never creates a place for himself within the family dynamic. Still plagued by the woes his father has heaped upon him, Smike has inherited a somewhat damning trait from Ralph, an inability to laugh.

The danger of the too much gravity is demonstrated in "The Five Sisters of York." In this tale, a Friar warns the cheerful young sisters not to enjoy themselves too much on earth, citing "The memory of earthly things is charged, in after life, with bitter disappointment, affliction, death; with dreary change and wasting sorrow" (63). This Friar ignores the beauty and joy around him, and while "everything looked gay and smiling...the holy man walked gloomily on, with his eyes bent upon the ground" (59). The Friar actively refuses to enjoy the world around him, believing such enjoyment to be against the will of God. In opposition, the youngest sister insists that "Nature's own blessings are the proper goods of life and we may share them sinlessly together" (62). The sisters live in unity in this way for some time, but, after the death of Alice, the elder sisters of the family decide to put away the amusements they once occupied themselves with together. Many gloomy years later, the sisters decide to look upon the colorful frames they had created, realizing that, despite the warnings of the Friar, "to call upon their old days shall be a solemn pleasure yet" (64). In doing so, the sisters finally determine to live together in joy as 
Alice had desired and shun the gloom of the veil the Friar had wished them to take. The Friar's unnecessary gravity causes him to lead a sorrowful life. Indeed, the Friar creates the gloomy world that he inhabits through his blatant refusal to enjoy the blessings of nature. His sorrow is not imposed, but self-created. In the same manner in which the Friar actively refuses "solemn pleasure," Ralph Nickleby refuses the ready amusement that lies around him. Schlicke describes Dicken's approach amusement as one of perception:

The mood of amusement in Sketches by Boz is controlled by the principle that the fascination of everyday scenes has only to be recognized to be enjoyed. Pleasure is thus dependent on the disposition of the beholder; whether he be participant, spectator or entertainer himself, a person's enjoyment arises from his own readiness to respond to the abundance of variety and stimuli available. (40)

A disposition of amusement, therefore, provides amusement itself. John Browdie engages in near constant festive laughter because he is constantly searching for entertainment in the world around him. He is more than willing to see Squeers, Nicholas, and even himself, as a clown. Ralph, in contrast, cannot find anything, let alone himself, to be amusing. He is blind to his own ridiculous nature.

In the world of carnival, the those who take themselves in earnest and fail to recognize their own festive potential are fated to die. They have no place in the festive jubilation of the new generation being birthed. Bahktin elaborates that the reason for the inevitable death of the grave representatives of the old authority is that "they do not recognize their own ridiculous faces or the comic nature of their pretentions to eternity and immutability. And thus these personages come to the end of their role still serious, although their spectators have been laughing for a long time" (213). Ralph cannot joke, let alone laugh at himself. He is unable to see the extremity of his cupidity, or his resemblance to the comic Pantaloon. He genuinely believes that his mad 
pursuit of money will allow him to continue in prosperity indefinitely. This poses a stark comparison to the optimistic comedy of Nicholas, Noggs, and Browdie, who all come to recognize the inevitable temporality of the various scenes of life.

The intensity of Ralph's gravity is apparent from the first presentation of his adult life. Ralph lives in a theatrical district, the boisterousness of which bears an obvious contrast to Ralph's sullen demeanor:

Sounds of gruff voices practicing vocal music invade the evening's silence; and the fumes of choice tobacco scent the air. There, snuff and cigars, and German pipes and flutes, and violins and violoncellos divide the supremacy between them. It is the region of song and smoke. Street bands are on their mettle in Golden Square; and itinerant gleesingers quavers involuntarily as they raise their voices within its boundaries. (7) A world of obvious entertainment surrounds Ralph, and yet he cares nothing for it, like the Friar, and is blind to his own theatricality. Schlicke further observes that "Dickens makes no suggestion that the music is anything other than cacophony, the inappropriateness of such a place for business serves as an implicit gloss on Ralph's character. The musicians are inoffensive in themselves, but no respectable gentleman would reside here" (69). The fact that Ralph resides in a theatrical district but is not a performer of any sort, but a business man of all things, signifies the probable dishonesty and even villainy of his business practices.

Ralph likewise fails to recognize the clownish faces that surround him. When Mr. Mantalini poisons himself (for the seventh time), Ralph clearly recognizes that the suicide is feigned, but only experiences irritation:

"You may put away those fooleries now, and live by your wits again," said Ralph, coolly putting on his hat. 


$$
\begin{aligned}
& \text { “Demmit, Nickleby, you're not serious?" } \\
& \text { "I'll seldom joke," said Ralph, “Good night." } \\
& \text { "No, but Nickleby,” said Mantalini. }
\end{aligned}
$$

"I am wrong, perhaps,” rejoined Ralph. "I hope so. You should know best. Good night." (589)

Ralph lacks the ability to amuse himself with the bizarre schemes of those with whom he interacts. The reader, however, laughs at Ralph at this juncture. Although he claims to "seldom joke" Ralph does in fact speak humorously when he insists that he hopes he is mistaken in thinking Mantalini is merely pretending to have poisoned himself. This scene aptly demonstrates Ralph's inability to perceive his own comic villainy.

In such a carnivaleqsue novel, Ralph's interminable gloom is a significant factor in his eventual death. Ralph initially has no consideration for his own mortality. The narrator notes that amongst all of Ralph's thoughts there was "not one word or figure denoting thought of death or the grave" (123). Ralph seems to, in some sense, believe that his success in business precludes any possibility of personal downfall, including death. Bahktin reveals that the "old authority and truth pretend to be absolute, to have an extratemporal importance. Therefore, their representatives (the agelasts) are gloomily serious" (212). Expounding further upon this principle Bahktin describes one such character destroyed by the "truth" of carnival. Ralph's gloom, and his seeming belief in his own perpetuity, foreshadows his own imminent death.

While the regular references to (near) suicide suggest that some actual suicide may occur within the course of the novel, Ralph's own self-destruction perhaps diverges from the typical path of carnival and pantomime alike. What occurs leading up to Ralph's suicide, however, reconcile the act of self-destruction with festive humor. In the hours before his death, Ralph witnesses a hump-backed drunk man dancing in the street: "He was a grotesque fantastic figure, 
and the few bystanders laughed. Ralph himself was moved to mirth, and echoed the laugh" (814). For the first time, Ralph recognizes the comic grotesque. The grotesque form that he witnesses is remarkably similar to Punch, or Pulcinella, one of the fools historically crowned at feast days. Finally moved to symbolically recognize a new form of hierarchy and authority, Ralph perceives his own obsolescence, and therefore his imminent destruction. This turns his own mind to the possibility of suicide: "When they had passed on, and he was left alone again, he resumed his speculation with a new kind of interest; for he recollected that the last person who had seen the suicide alive, had left him very merry, and he remembered how strange he and the other jurors had thought that, at the time" (814). The liminal nature between merriment and despair becomes apparent; it is a grotesque comedy that kills the old generation while birthing the new. Admitting himself to be a part of the old authority, in the process of being replaced by Nicholas and other representatives of a newer world, Ralph takes his own life. 


\section{CONCLUSION}

Dickens utilizes characters and situations of popular theatrical forms, including the pantomime, melodrama, "The Punch and Judy Show" and the circus. Dickens's use of such forms within his novels, and Nicholas Nickleby in particular, is sourced from his belief in the “pantomime of life;" Dickens found theatrical clowns and amusement in everyday life. Despite the concern of moralists that these forms of entertainment would encourage immoral behavior in their viewers, Dickens instead demonstrates the effective social use of popular amusement, and specifically values the carnivalesque hierarchical subversion that occurs in the act of laughter. Laughter and comic subversion are used by Nicholas in order avenge himself (and others) and revolt against oppressive characters, such as Squeers, Ralph, and Hawk. The audience of the novel, in witnessing the dismantlement of hierarchy through laughter and comic retaliation, may be encouraged to live within the wider bounds of comedy themselves, adopting a tendency towards amusement in order to diminish the greatness of the oppressive powers met in everyday life. 


\section{BIBLIOGRAPHY}

Altick, Richard. The Shows of London. Belknap Press, 1978.

Axton, William. Circle of Fire: Dicken's Vision and Style and the Victorian Popular Theatre. University of Kentucky Press, 1966.

Allingham, Philip V. “Charles Dickens and Punch.” Update, vol. 39, no. 1, Jan. 1997, pp. 17libproxy.lib.ilstu.edu/login?url=https://search.ebscohost.com/login.aspx?direct=true\&db $=$ mzh\&AN=1997066432\&site=ehost-live $\&$ scope $=$ site.

Bahktin, Mikhail. Rabelais and His World. MIT Press, 1968.

Collins, Philip. “Dickens and Punch.” Dickens Studies, vol. 3, 1967, pp. 4-21. EBSCOhost,

Chesterton, G.K. Charles Dickens, The Last of Great Men. The Press of the Readers Club, 1942. libproxy.lib.ilstu.edu/login?url=https://search.ebscohost.com/login.aspx?direct=true \&db= mzh\&AN=1967107560\&site=ehost-live \&scope $=$ site.

Crotch, Walter. The Pageant of Dickens. Chapman and Hall, 1915.

Cruikshank, George and Karl B. Leabo. The Tragical Comedy, or Comical Tragedy, of Punch and Judy. Theatre Arts Books, 1983.

Dickens, Charles. Hard Times. Barnes and Noble Classics, 2004.

-----. “London Recreations.” Sketches by Boz and Other Early Papers 1833-39. Ed. Michael

Slater. Ohio State University Press, 1994, pp. 94-99.

------. The Memoirs of Joseph Grimaldi. MacGibbon and Key, 1968.

------. Nicholas Nickleby. Barnes and Noble Classics, 2005.

------. The Old Curiosity Shop. Penguin Classics, 2000. 
-----. “The Pantomime of Life.” Sketches by Boz and Other Early Papers 1833-39. Ed. Michael Slater. Ohio State University Press, 1994, pp. 500-507.

------. "Private Theatres." Sketches by Boz and Other Early Papers 1833-39. Ed. Michael Slater. Ohio State University Press, 1994, pp. 120-126.

------. Selected Journalism 1850-1870. Penguin Classics, 1997.

Eigner, Edwin, M. The Dickens Pantomime. University of California Press, 1989.

Enders, Jody. "Two Priests and the Hand of God," Death by Drama and Other Medieval Urban Legends. University of Chicago Press, 2002, pp. 55-66.

Jones, Louisa E. Sad Clowns and Pale Pierrots: Literature and Popular Comic Arts in $19^{\text {th }}$ Century France. French Forum Publishers, 1984.

Leach, Robert. The Punch and Judy Show: Tradition, History, and Meaning. Batsford Academic and Educational, 1985.

Napolitano, Marc. “A Melodious Anti-Melodrama-Underscoring, Song and Parody in the Royal Shakespeare Company's Life and Adventures of Nicholas Nickleby." Journal of Adaptation in Film and Performance, vol. 5, no. 2, 2012, pp. 167-182. EBSCOhost, libproxy.lib.ilstu.edu/login?url=https://search.ebscohost.com/login.aspx?direct=true\&db= mzh\&AN=2012444437\&site=ehost-live\&scope=site.

Schlicke, Paul. "Dickens in The Circus." Theatre Notebook: A Journal of the History and Technique of the British Theatre, vol. 47, no. 1, 1993, pp. 3-19. EBSCOhost, libproxy.lib.ilstu.edu/login?url=https://search.ebscohost.com/login.aspx?direct=true\&db= mzh\&AN=2001140524\&site=ehost-live \&scope=site.

------. Dickens and Popular Enteraintment. Allen and Unwin, 1985. 
----. Oxford Reader's Companion to Dickens. Oxford University Press, 2000.

Tomalin, Claire. Charles Dickens: A Life. The Penguin Press, 2011.

Wilde, Oscar. The Complete Letters of Oscar Wilde. Edited by Merlin Holland and Rupert Hart-

Davis. Henry Holt, 2000. 